\section{Australian Journal of \\ Crop Science}

AJCS

ISSN:1835-2707

AJCS 13(04):529-535 (2019)

doi: 10.21475/ajcs.19.13.04.p1432

\title{
Use of different doses of glyphosate to control invasive plants: Bidens pilosa, Commelina benghalensis, Digitaria insularis, Ipomoea grandiofolia and Tridax procumbens
}

\author{
André Luiz de Souza Lacerda ${ }^{1}$, Ricardo Victoria Filho ${ }^{2}$, Zigomar Menezes de Souza ${ }^{3}$, José Luiz Rodrigues \\ Torres $^{4^{*}}$
}

${ }^{1}$ Valinhos City Hall (SP), Agronomist, PhD, Rua Antônio Carlos, 301, CEP. 13.270-005, Valinhos, São Paulo, Brazil

${ }^{2}$ School of Agriculture "Luiz de Queiroz" (ESALQ/USP) - Professor, PhD, Department of Plant Production, CP 9 - Zip code . 13.417-950 - Piracicaba, SP - Brazil

${ }^{3}$ University of Campinas (UNICAMP), School of Agricultural Engineering (FEAGRI) - Av. Cândido Rondon, 501, Barão Geraldo, 13.083-875, Campinas, São Paulo, Brazil

${ }^{4}$ Institute Federal of Education, Science and Technology, Triângulo Mineiro, Uberaba, Brazil, PhD in Agronomy/Plant Production, Rua João Batista Ribeiro, 4000, Zip code 39064-790, Brazil

*Corresponding author: jIrtorres@iftm.edu.br

\begin{abstract}
Glyposhate is among the most widely used herbicides in Brazil and worldwide and has a broad spectrum of control, low toxicity, non-selective, and systemic action. In Brazil, it has been increasingly consumed after its release to be used in plants with tolerance to the product; however, excessive use has contributed to select resistant or tolerant weed species. Our goal was to evaluate the efficiency of weed control by using glyphosate in a growth chamber at different doses, periods of applications, and weed species. The experimental design was completely randomized - factorial scheme $7 \times 5$ - by assessing seven doses of glyphosate: 0; 720; 960; 1200; 1440; 1680, and $1920 \mathrm{~g} \mathrm{ha}^{-1}$ i.a., in five weeds: black picket, bitter grass, bull herb, viola string, and ragged, with five repetitions. The weeds were sowed in polyethylene pots with three plants per pot. Assessments of dry biomass were conducted after 7, 14, and 21 days of application (DAA) with the treatment of glyphosate in scores from 0 to $100 \%$. We concluded that the herbicide was efficient at controlling the black picket and bitter grass species as $100 \%$ of the weed plants 14 DAA died with the doses of $720 \mathrm{~g} \mathrm{ha}^{-1} \mathrm{i}$.a. Doses of glyphosate required to reach indices of control above 915 were $1680 \mathrm{~g} \mathrm{ha}^{-1}$ i.a. for ragged, $960 \mathrm{~g}$ ha ${ }^{1}$ i.a. for bull herb, and $1440 \mathrm{~g} \mathrm{ha}^{-1}$ i.a. for viola string at $21 \mathrm{DAA}-$ since these are considered hard to control. It is recommended to apply $1440 \mathrm{~g}$ ha- 1 i.a. of glyphosate for an effective control over $80 \%$ of all invasive plants assessed at 21 DAA,
\end{abstract}

Keywords: weed, chemical control, herbicide.

Abbreviations: CRD _ Completely randomized design, g ha _ Grams per hectare, DAA _ Days after application, g e. a. _ Grams per active ingredient, ha _Hectare, $S_{-}$Species, D_Doses, $C$ canadensis_Conyza canadensis, $C$. bonariensis_Conyza bonariensis, $C$ sumatrensis_Conyza sumatrensis, $C$ benghalensis_Commelina benghalensis, I grandiofolia_ Ipomoea grandiofolia, E heterophylla _Euphorbia heterophylla, $T$ procumbens_ Tridax procumbents, B. pilosa _ Bidens pilosa, D. insularis__ Digitaria insularis, DB_Dry biomass.

Introduction

Glyphosate has been used to control weeds for many years in several production systems and is among the most widely used herbicides in Brazil and worldwide; in addition, it has a systemic action, broad-spectrum control, and low toxicity to non-target organisms (Christoffoleti et al., 2008). In Brazil, it has been used for more than 30 years, which has been increasing after the its release to be used in genetically modified tolerant plants - in some areas up to three applications have been made in the same crop cycle (Moreira et al., 2007).

According to lkeda (2013), such an increase in use is largely related to the flexibility of glyphosate at controlling weeds at different development stages since it is a non-selective herbicide applied in a post-emergence period to control perennial and annual weed species, with broad or narrow leaves; in addition to the fact that the plant necrosis and death occur within just a few days. However, Koger and Reddy (2005) point out to the frequent use of this active principle, due to the excess of applications, as a significant contribution to the selection of resistant and/or tolerant biotypes in weed species.

According to Christoffoleti and Lopez Ovejero (2008) and Kissmann (2013), weeds become resistant to the herbicide when a group of plants is able to survive and reproduce after being exposed to the commonly applied dose, which would normally be lethal to a susceptible population of the same 
species. According to Monquero et al. (2005), Ferreira et al. (2009) and Dalazen et al. (2015), this occurs for glyphosate with fleabanes (Conyza canadensis, C. bonariensis and $C$. sumatrensis), bitter grass (Digitaria insularis), milkweed (Euphorbia heterophylla), Italian ryegrass (Lolium multiflorum), among others.

In turn, Ferreira et al. (2009), Ikeda (2013), Takano et al. (2013) and Marchi et al. (2013) define tolerance as the ability of some species to survive and reproduce after treatment with herbicides, even when suffering from injuries. This has occurred for glyphosate in broadleaf species and in more advanced development stages, which has proved common in ragged (Commelina benghalensis L.), bull herb (Tridax procumbens L.), hot herb (Spermacoce latifolia Aubl.), viola string (Ipomoea grandiofolia L.), Brazilian pusley (Richardia brasiliensis), fire-extinguisher (Alternanthera tenella Colla), Johnson grass (Sorghum halepense (L.) Pers.), among others.

Some studies using doses of glyphosate have indicated that the control of some weeds has not been satisfactory. Correia et al. (2008) used high doses of glyphosate (1200 g e.a. ha ${ }^{-1}$ ) to control ragged ( $C$. benghalensis) population using plants with four to six leaves and found low efficiency (42.5\%). As for fleabanes (Conyza sp.), Yamauti et al. (2010) conducted sequential applications of glyphosate at 720 e.a. ha ${ }^{-1}$ and observed a control ranging only $54.8 \%$. Ramires et al. (2010) applied 960 e.a. ha ${ }^{-1}$ of pure glyphosate in viola string ( $I$. grandiofolia L.) for plants with four to six leaves and obtained control of $76.2 \%$.

Procópio et al. (2007) assessed the isolated application of glyphosate at doses of 480,960, and 1.440 g e.a. ha ${ }^{-1}$, and found efficiency values of 40,55 , and $65 \%$ in milkweed $(E$. heterophylla) applied with four to eight leaves; 30, 40, and $55 \%$ in ragged ( $C$. benghalensis) with two to six leaves; 50 , 50 , and $55 \%$ in viola string (I. grandifolia) with two to six leaves, as well as 30,55 , and $65 \%$ in asthma plant (Chamaesyce hirta) with two to six leaves, 25 days after the application, respectively.

In general, the growth of weeds resistant to herbicides can be said to result from their incorrect use since the repetition of a single herbicide or mechanism of action induces a quick development of resistant biotypes (Ferreira et al., 2009). For this reason, the intense use of glyphosate in agricultural areas has favored selection pressure, which, combined with the good ecological adaptability of weed species and the use of inadequate doses, has contributed to select tolerant or resistant species. In this context, our study aimed at evaluating the control efficiency of glyphosate in a growth chamber at different doses, periods of application, and weed species.

\section{Results and discussions}

The analysis of data variance revealed a significant effect for the species (S) and doses (D) as well as an interaction between the assessed parameters $(S \times D)$ (Table 1).

\section{Percentage of control of invasive plants}

The analysis of the control percentage for the plants assessed revealed values significantly higher along the sequence 21>14>7 DAA for all evaluated species (Table 2). However, the minimum $80 \%$ control predicted in the legislation was found only at 14 DAA for B. pilosa and $D$. insularis, which increased significantly at 21 DAA for all weeds. Still, for $I$. grandifolia and C. benghalensis the minimum amount required by law could not be reached.

On day 7 of treatment using DAA with glyphosate, the $D$. insularis and $B$. pilosa species were controlled at levels above $65 \%$, whereas $T$. procumbens, I. grandifolial, and $C$. benghalensis below $60 \%$. C. benghalensis had the lowest percentage control value (25\%). Such differences in control were significant for all species, except for B. pilosa $(66 \%)$ and D. insularis (70\%), which did not differ.

On day 14, the control indices increased for all species with values considered excellent (86\%) for B. pilosa and $D$. insularis, good for $T$. procumbens (78\%), and regular for $C$. benghalensis, I. grandifolia (between 60 and 41\%), according to the scale proposed by Alam (1974).

On day 21 , control remained constant for $B$. pilosa and $D$. insularis (86\%) while increased for the remaining species, reaching $83 \%$ for $T$. procumbens, $74 \%$ for I. grandifolia and $72 \%$ for $C$. benghalensis. Thus, the treatment was regarded at least good for all plants assessed, however, only three reached the acceptable level of control established in the current legislation $-80 \%$.

\section{The stage of invasive plant development}

The plant development stage may alter the effect of glyphosate since both height and leaf number influence the efficiency of the product (Vidal et al., 2014). A similar study by Marchi et al. (2013)evaluated the efficiency of glyphosate at controlling ragged (Commelina benghalensis L.) on days 7 , 14, 21, and 30 after the application (DAA) found the percentage control advancing slowly and reaching levels above $80 \%$ only for the assessment performed on day 21 DAA - dose of $960 \mathrm{~g} \mathrm{ha}^{-1}$ i.a.

According to Carvalho et al. (2008), under field conditions, control efficiency is affected by the climatic condition at the time of application. Considering that it had rained on the eve of the application, the efficiency could increase, as the sediments or the excessive amount of dust on the leaves had been removed facilitating better absorption of the product applied. However, if it had rained soon after the application, the leaves would have been washed and the control efficiency decreased significantly; although, such conditions are controlled in a greenhouse.

Dry biomass production of B. pilosa $(0.64 \mathrm{~g})$, I. grandifolia $(0.67 \mathrm{~g})$ and $C$. benghalensis $(0.60 \mathrm{~g})$ were statistically equal ( $p<0.05$ ) and above the values recorded for $D$. insularis $(0.38 \mathrm{~g})$ and $T$. procumbens $(0.20 \mathrm{~g})$, which proves that weed control is more effective when the application is conducted at the ideal stage (four to six leaves).

The assessment of glyphosate dose at $720 \mathrm{~g} \mathrm{ha}^{-1}$ i.a. at the E1 (two to four leaves), E2 (four to six leaves), and E3 (six to 10 leaves) stages for species considered difficult to control (Commelina benghalensis, Richardia brasiliensis, Euphorbia heterophylla, Spermacoce Iatifolia, Ipomoea grandifolia, and Conyza spp.) by Takano et al. (2013) foud that the control is higher with an application at the early stages of weed development - more effective along the sequence $2-4>4$ -6 and $>10$ leaves. 
Table 1. Analysis of the variances of the treatments (species) and applied doses of glyphosate in the evaluated weeds at 7,14 and 21 days after application of glyphosate.

\begin{tabular}{llllll}
\hline Evaluation & GL & 7 DAA & 14 DAA & 21 DAA & DB \\
\hline Species (S) & 4 & $220.28^{* *}$ & $879.68^{* *}$ & $178.60^{* *}$ & $34.34^{* *}$ \\
Doses (D) & 6 & $260.88^{* *}$ & $2148.35^{* *}$ & $3622.54^{* *}$ & $283.77^{* *}$ \\
S x D & 24 & $10.52^{* *}$ & $47.85^{* *}$ & $31.86^{* *}$ & $20.80^{* *}$ \\
\hline
\end{tabular}

A
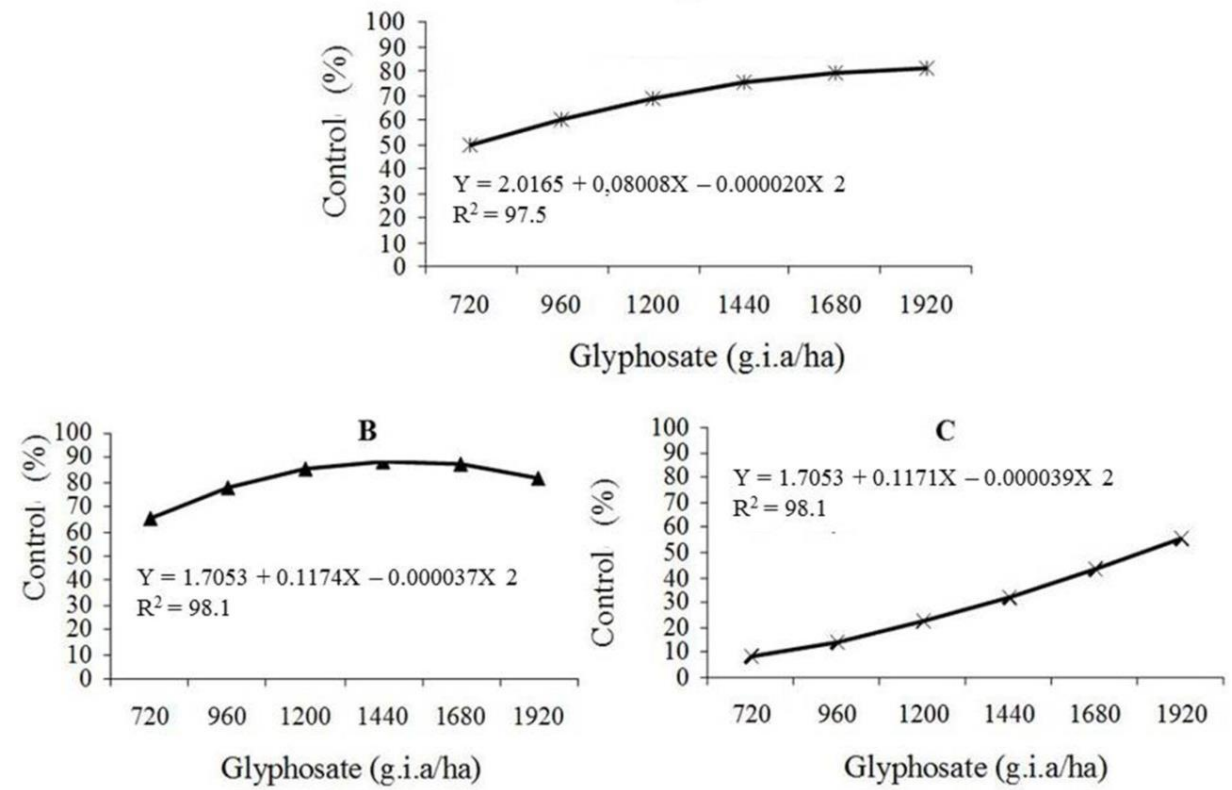

Fig 1. Model adjusted for the control (\%) of bull herb (T. procumbens L.) (A), ragged (C. benghalensis L.) (B) and bitter grass (D. insularis L. (Fedde)) (C), respectively, at 7 DAA of glyphosate.

Table 2. Percentage of control and dry biomass (DB) of Black picket (Bidens pilosa L.), Bitter grass (Digitaria insularis L. (Fedde)), Bull herb (Tridax procumbens L.), viola string (Ipomoea grandiofolia L.) and ragged (Commelina benghalensis L.) at 7, 14 and 21 days after application (DAA) of glyphosate.

\begin{tabular}{|c|c|c|c|c|}
\hline \multirow[t]{2}{*}{ Invasive Plants } & 7 DAA & 14 DAA & $21 \mathrm{DAA}$ & \multirow{2}{*}{$\begin{array}{l}\mathrm{DB} \\
\mathrm{g}\end{array}$} \\
\hline & \multicolumn{3}{|c|}{ 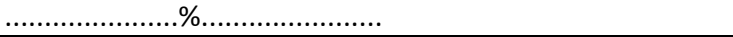 } & \\
\hline B. pilosa & $66 a^{*}$ & $86 a^{*}$ & $86 a^{*}$ & $0.64 a^{*}$ \\
\hline D. insularis & $70 \mathrm{a}$ & $86 \mathrm{a}$ & $86 \mathrm{a}$ & $0.38 \mathrm{~b}$ \\
\hline T. procumbens & $59 \mathrm{~b}$ & $78 \mathrm{~b}$ & $83 \mathrm{~b}$ & $0.20 \mathrm{c}$ \\
\hline I. grandifolia & $38 \mathrm{c}$ & $59 \mathrm{c}$ & $74 \mathrm{c}$ & $0.67 \mathrm{a}$ \\
\hline C. benghalensis & $25 \mathrm{~d}$ & $46 d$ & $72 \mathrm{~d}$ & $0.60 \mathrm{a}$ \\
\hline DMS & 5 & 2 & 2 & 0.13 \\
\hline CV (\%) & 15 & 5 & 4 & 41 \\
\hline
\end{tabular}

= Means followed by the same letter in the column do not statistically differ from each other in Tukey's test on the $5 \%$ threshold. DMS = Significant minimal difference; CV $=$ Coefficient of variation.

A

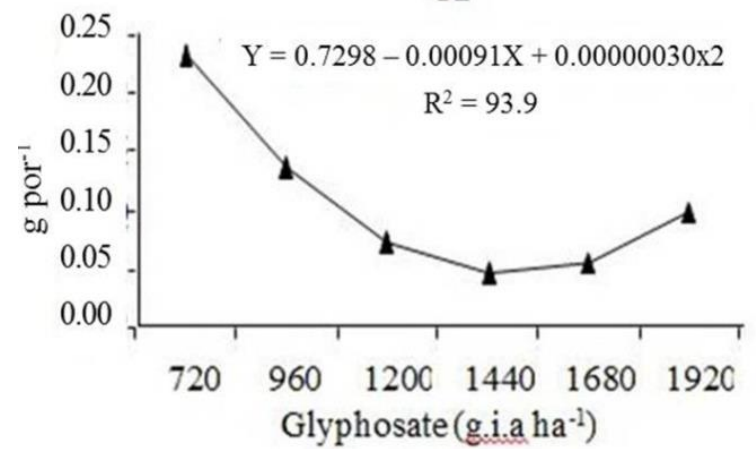

\section{B}

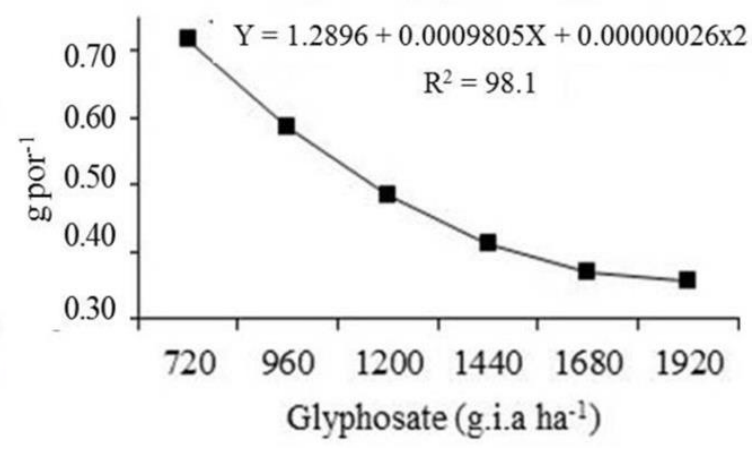

Fig 2. Model adjusted for the dry biomass $\left(\mathrm{g} \mathrm{pot}^{-1}\right.$ ) of the aerial part of the $C$. benghalensis (A) and T. procumbens (B) species, respectively, according to the doses of glyphosate. 
Table 3. Development of the interaction species $x$ doses regarding weed control at 7,14 and 21 days after application of glyphosate ${ }^{1}$.

\begin{tabular}{|c|c|c|c|c|c|c|}
\hline \multirow[t]{3}{*}{ Invasive Plants } & \multicolumn{6}{|c|}{ Doses of glyphosate } \\
\hline & 720 & 960 & 1200 & 1440 & 1680 & 1920 \\
\hline & \multicolumn{6}{|c|}{.................... g ha ${ }^{-1}$ i.a.................... } \\
\hline & \multicolumn{6}{|l|}{7 days } \\
\hline B. pilosa & $73 \mathrm{Aa}$ & $72 \mathrm{Aa}$ & $78 \mathrm{Aa}$ & $78 \mathrm{Aba}$ & $80 \mathrm{Aa}$ & $84 \mathrm{Aa}$ \\
\hline D. insularis & $72 \mathrm{Aa}$ & $79 \mathrm{Aab}$ & $78 \mathrm{Aab}$ & $90 \mathrm{Aa}$ & 86 Aab & 85 Aab \\
\hline T. procumbens & $57 \mathrm{Bc}$ & $58 \mathrm{Bc}$ & $66 \mathrm{Abc}$ & $74 \mathrm{Bab}$ & $75 \mathrm{Aab}$ & $85 \mathrm{Ab}$ \\
\hline I. grandifolia & $21 \mathrm{Cc}$ & $26 \mathrm{Cbc}$ & $37 \mathrm{Bb}$ & $59 \mathrm{Ca}$ & $57 \mathrm{Ba}$ & $63 \mathrm{Ba}$ \\
\hline C. benghalensis & $7 \mathrm{Dc}$ & $12 \mathrm{Dc}$ & $27 \mathrm{Bb}$ & $28 \mathrm{Db}$ & $49 \mathrm{Ba}$ & $53 \mathrm{Ba}$ \\
\hline \multirow[t]{2}{*}{ CV (\%) } & \multicolumn{6}{|c|}{ 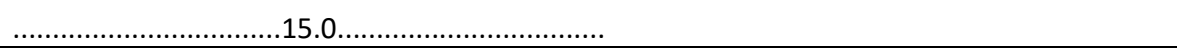 } \\
\hline & \multicolumn{6}{|l|}{14 days } \\
\hline B. pilosa & $100 \mathrm{Aa}$ & $100 \mathrm{Aa}$ & $100 \mathrm{Aa}$ & $100 \mathrm{Aa}$ & $100 \mathrm{Aa}$ & $100 \mathrm{Aa}$ \\
\hline D. insularis & $100 \mathrm{Aa}$ & $100 \mathrm{Aa}$ & $100 \mathrm{Aa}$ & $100 \mathrm{Aa}$ & $100 \mathrm{Aa}$ & $100 \mathrm{Aa}$ \\
\hline T. procumbens & $78 \mathrm{Ba}$ & $83 \mathrm{Bab}$ & $84 \mathrm{Bb}$ & $88 \mathrm{Bb}$ & $93 \mathrm{Bbc}$ & $97 \mathrm{Ac}$ \\
\hline I. grandifolia & $59 \mathrm{Ca}$ & $64 \mathrm{Cab}$ & $68 \mathrm{Bb}$ & $73 \mathrm{Cb}$ & $89 \mathrm{BC}$ & $93 \mathrm{Ab}$ \\
\hline C. benghalensis & $27 \mathrm{Da}$ & $42 \mathrm{Db}$ & $54 \mathrm{BC}$ & $62 \mathrm{Dd}$ & $69 \mathrm{Ce}$ & $72 \mathrm{Be}$ \\
\hline \multicolumn{7}{|l|}{$\mathrm{CV}(\%)$} \\
\hline & \multicolumn{6}{|l|}{21 days } \\
\hline B. pilosa & $100 \mathrm{Aa}$ & $100 \mathrm{Aa}$ & $100 \mathrm{Aa}$ & $100 \mathrm{Aa}$ & $100 \mathrm{Aa}$ & $100 \mathrm{Aa}$ \\
\hline D. insularis & $100 \mathrm{Aa}$ & $100 \mathrm{Aa}$ & $100 \mathrm{Aa}$ & $100 \mathrm{Aa}$ & $100 \mathrm{Aa}$ & $100 \mathrm{Aa}$ \\
\hline T. procumbens & $88 \mathrm{Ba}$ & $95 \mathrm{Ab}$ & $97 \mathrm{Abc}$ & $100 \mathrm{Ac}$ & $100 \mathrm{Ac}$ & $100 \mathrm{Ac}$ \\
\hline I. grandifolia & $81 \mathrm{Ca}$ & $84 \mathrm{Ca}$ & $84 \mathrm{Ba}$ & $93 \mathrm{Bb}$ & $99 \mathrm{Ac}$ & $98 \mathrm{BC}$ \\
\hline C. benghalensis & $54 \mathrm{Da}$ & $74 \mathrm{Db}$ & $78 \mathrm{Cb}$ & $85 \mathrm{Cc}$ & $98 \mathrm{Ad}$ & $92 \mathrm{Be}$ \\
\hline CV (\%) & ........ & ................. & 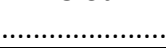 & $\ldots \ldots$ & & \\
\hline
\end{tabular}

${ }^{1} \mathrm{Means}$ followed by the same lowercase letter in the row and upper case in the column do not statistically differ from each other in Tukey's test $(\mathrm{p}<0.05)$. CV = Coefficient of variation.

Table 4. Dry biomass from of black picket (Bidens pilosa L.), bitter grass (Digitaria insularis L. (Fedde)), bull herb (Tridax procumbens L.), viola string (Ipomoea grandiofolia L.) and ragged (Commelina benghalensis L.) at different doses of glyphosate.

\begin{tabular}{|c|c|c|c|c|c|}
\hline \multirow{3}{*}{$\begin{array}{l}\text { Doses } \\
\text { g ha }{ }^{-1} \text { i.a. }\end{array}$} & \multicolumn{5}{|c|}{ Dry biomass } \\
\hline & B. pilosa & D. insularis & T.procumbens & I. grandifolia & C. benghalensi \\
\hline & \multicolumn{5}{|c|}{ 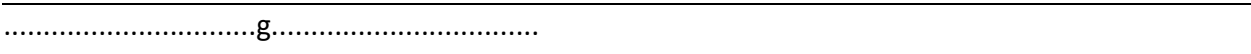 } \\
\hline 0 & $3.432 \mathrm{a}^{1}$ & $2.260 a^{1}$ & $0.756 a^{1}$ & $2.592 a^{1}$ & $1.286 a^{1}$ \\
\hline 720 & $0.202 b$ & $0.038 \mathrm{~b}$ & $0.164 \mathrm{~b}$ & $0.400 \mathrm{~b}$ & $0.694 \mathrm{~b}$ \\
\hline 960 & $0.214 \mathrm{~b}$ & $0.054 \mathrm{~b}$ & $0.098 \mathrm{~b}$ & $0.390 \mathrm{~b}$ & $0.628 \mathrm{bc}$ \\
\hline 1200 & $0.142 b$ & $0.078 \mathrm{~b}$ & $0.122 \mathrm{~b}$ & $0.440 \mathrm{~b}$ & $0.534 \mathrm{bc}$ \\
\hline 1440 & $0.122 \mathrm{~b}$ & $0.033 \mathrm{~b}$ & $0.072 \mathrm{~b}$ & $0.210 \mathrm{~b}$ & $0.348 \mathrm{bc}$ \\
\hline 1680 & $0.160 \mathrm{~b}$ & $0.100 \mathrm{~b}$ & 0.142 b & $0.312 b$ & $0.330 \mathrm{bc}$ \\
\hline 1920 & $0.198 \mathrm{~b}$ & $0.126 \mathrm{~b}$ & $0.020 \mathrm{~b}$ & $0.378 b$ & $0.398 \mathrm{bc}$ \\
\hline CV (\%) & \multicolumn{5}{|c|}{ 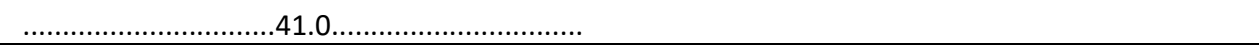 } \\
\hline
\end{tabular}

\section{The interactions between weed control and glyphosate doses}

The analysis of the interaction between species and doses revealed that on day 7 DAA of glyphosate, control rates were very low in $C$. benghalensis, ranging from $7 \%$ at the lowest dose $\left(720 \mathrm{~g} \mathrm{ha}^{-1} \mathrm{i}\right.$.a.) to $53 \%$ at the highest dose (1920 $\mathrm{g} \mathrm{ha}^{-1}$ i.a.) (Table 3) - reaching the regular standard. For all doses assessed, control rates for $I$. grandifolia and $C$. benghalensis ranged from poor to regular, for B. pilosa and $D$. insularis from good to very good, whereas $T$. procumbens ranged from regular to good, the second classification proposed by Alam (1974).

On day $14 \mathrm{DAA}$, the total control was achieved for B. pilosa and $D$. insularis at all assessed doses, while it significantly increased for $T$. procumbens and I. grandifolia and reached the excellent level at the two largest doses (1680 and $1920 \mathrm{~g}$ ha ${ }^{-1}$ i.a.); for $C$. benghalensis, though, the control ranged from poor to good.

Monquero et al. (2005) and Procópio et al. (2007) obtained similar results for the ragged ( $C$. benghalensis) - increased control levels. Carvalho et al. (2008) emphasized that no treatment with glyphosate was effective at controlling this weed, having reached the highest level on day 14 DAA $50 \%$ with at $1440 \mathrm{~g} \mathrm{ha}^{-1}$ i.a. In turn, Timossi et al. (2006) found that the application of glyphosate $1440 \mathrm{~g} \mathrm{ha}^{-1}$ i.a. was effective for the management of the plants assessed (Bitter grass, Grass burr, fire-extinguisher), except for ragged, which was tolerant to glyphosate at doses up to $2880 \mathrm{~g} \mathrm{ha}^{-1}$ i.a. On day 21 , at the lowest dose assessed ( $720 \mathrm{~g} \mathrm{ha}^{-1}$ i.a.), the control ranged from 54 to $100 \%$, whereas at the highest dose $\left(1920 \mathrm{~g} \mathrm{ha}^{-1}\right.$ i.a.) it ranged from 92 to $100 \%$ for all weeds assessed. This indicates that at doses above $960 \mathrm{~g}$ ha ${ }^{1}$ i.a., control can be considered good ( $\left.81-70 \%\right)$, according to the scale proposed by Alam (1974). 
Similar results were achieved by Rodrigues and Almeida (2011) by assessing the application of different glyphosate concentrations in a single application or along sequential applications at doses of 480; 720; 960; 1200 , and $1440 \mathrm{~g} \mathrm{ha}^{-1}$ i.a. on day 31 after emergence (DAE). The authors applied $720 \mathrm{~g} \mathrm{ha}^{-1}$ i.a. on day $22 \mathrm{DAE}, 480 \mathrm{~g} \mathrm{ha}^{-1}$ i.a. on day $42 \mathrm{DAE}$, $960 \mathrm{~g} \mathrm{ha}^{-1}$ i.a. on day $22 \mathrm{DAE}$, and $720 \mathrm{~g} \mathrm{ha}^{-1}$ i.a. on day 42 DAE. All doses were efficient at controlling $T$. procumbens and $I$. grandifolia in the area. The authors also found that it was only 21 days after glyphosate application and at the highest dose that control values above $91 \%$ were obtained for the $C$. benghalensis species. The doses required in our study to achieve control rates of 98 and $92 \%$ consisted of 1680 and $1920 \mathrm{~g} \mathrm{ha}^{-1}$ i.a., respectively.

Santos et al. (2001) obtained a control of $94 \%$ when studying C. benghalensis inside polyethylene boxes in an unprotected area by applying glyphosate at the flowering stage, initially at $720 \mathrm{~g} \mathrm{ha}^{-1}$ i.a. 25 days after application (DAA), with $100 \%$ at 63 DAA with $720,1440,2160,2880$, and $3600 \mathrm{~g} \mathrm{ha}^{-1}$ i.a. The species $B$. pilos $a$ and $D$. insularis reached values equal to $100 \%$ on day 14 DAA at $720 \mathrm{~g} \mathrm{ha}^{-1}$ i.a., whereas $T$. procumbens reached $100 \%$ control at $1440 \mathrm{G} \mathrm{ha}^{-1}$ i.a. on day 21 DAA.

Ramires et al. (2011) studied the control of Ipomoea grandifolia by using pure glyphosate or associated with latifolicides in the $\mathrm{RR}^{\circledast}$ soybean crop and found higher efficacy in relation to the application of pure glyphosate at $480 \mathrm{~g} \mathrm{ha}^{-1}$ i.a. upon the use of this herbicide with protoxinhibiting herbicides. The authors also mentioned that mixtures containing glyphosate at $960 \mathrm{~g} \mathrm{ha}^{-1}$ i.a. and other post-emergent herbicides (cloransulam-methyl, chlorimuron-ethyl, imazethapyr, lactofen, fomesafen, flumiclorac-pentyl, and bentazon) provided improved control efficiency, regardless the leaf stage of the weeds "two to three" or "four to six.

\section{Control of biomass production of the invasive plant} provided by the herbicide

In the evaluation of the dry biomass (DB) of the evaluated weeds, the effectiveness of the herbicide glyphosate was verified in the control of the species. The application of glyphosate at $720 \mathrm{~g} \mathrm{ha}^{-1}$ i.a. was sufficient to provide the amount of DB significantly $(p<0.05)$ lower in all the plants if compared with the control. This effect is greater as the herbicide doses increased; however, there were no differences, except for $C$. benghalensis, between doses of 720 and $1920 \mathrm{~g} \mathrm{ha}^{-1}$ i.a. (Table 4).

The regression analysis reveals that the quadratic $\left(R^{2}=0.98\right)$ model had the best adjustment to $T$. procumbens species seven days after the herbicide application; it showed that the higher herbicide dose the better the control of the species up to a maximum value of about $80 \%$ for the dose of $1920 \mathrm{~g} \mathrm{ha}^{-1}$ i.a. and $50 \%$ for $720 \mathrm{~g} \mathrm{ha}^{-1}$ i.a. (Figure 1 ).

For $C$. benghalensis, the quadratic mathematical model equation $\left(R^{2}=0.96\right)$ has a concave shape indicating better control of this species as the doses of glyphosate increases; however, the control percentage values are lower when than T. Procumbens, which indicates more difficulties to control this species at the doses tested. For $D$. insularis, the highest control percentage occurred at $1440 \mathrm{~g} \mathrm{ha}^{-1}$ i.a., above $80 \%$, a dose at which control begins to decline perhaps indicating a lower absorption or efficiency of the herbicide for this species and causing regrowth.

The regression analysis showed that the quadratic $\left(R^{2}=\right.$ 0.98) mathematical model had the best adjustment revealing effective control with considerable reductions of dry biomass of $C$. benghalensis plants and higher glyphosate doses (Figure 2), since $C$. benghalensis DB decreased from 0.71 to $0.41 \mathrm{~g} /$ pot as the glyphosate dose doubled from 720 to $1440 \mathrm{~g} \mathrm{ha}^{-1}$ i.a., enabling a reduction of $57 \%$ in dry biomass. At the doses of 1680 and $1920 \mathrm{~g} \mathrm{ha}^{-1}$ i.a. such a decrease becomes lower and the curve less steep as the biomass is reduced from 0.36 to $0.35 \mathrm{~g} /$ pot, respectively.

Marchi et al. (2013) assessed the Commelina benghalensis species present in high infestations in $\mathrm{RR}^{\circledR}$ soybean crops and found that the control of this species can be obtained with only one glyphosate application at $960 \mathrm{~g} \mathrm{ha}^{-1}$ i.a. when associated with the post-emergent herbicides cloransulammethyl, chlorimuron-ethyl, imazethapyr or lactofen, without significant loss in productivity.

Significant quadratic regression was found in $T$. procumbens, in which doses of $720 ; 960 ; 1200$, and $1440 \mathrm{~g} \mathrm{ha}^{-1}$ i.a. provided the species with lower DB production. With the application of a higher dose - from 1680 to $1920 \mathrm{~g} \mathrm{ha}^{-1}$ i.a. the DB production of the species increased from 0.056 to $0.099 \mathrm{~g} /$ pot, respectively, for the dose of $1440 \mathrm{~g} \mathrm{ha}^{-1}$ i.a. (Figure 2). Foloni et al. (2005) observed that the control of $T$. procumbens on days 20 and 51 DAA was susceptible to glyphosate at $480,720,960,1200$, and $1440 \mathrm{~g} \mathrm{ha}^{-1}$ i.a. on day 31 after emergence (DAE). However, the authors found that on days 20 and 51 DAA, the application of glyphosate at $1440 \mathrm{~g} \mathrm{ha}^{-1}$ i.a. provided a statistically superior control in relation to the values obtained with applications of 480 and $720 \mathrm{~g} \mathrm{ha}^{-1}$ i.a.

\section{Materials and methods}

\section{Location of the experimental area}

The study was conducted in an experimental area located in the municipality of Piracicaba - SP, Brazil, under the geographical coordinates of $22^{\circ} 42^{\prime} 9^{\prime \prime}$ south latitude and $47^{\circ} 38^{\prime} 30^{\prime \prime}$ west longitude and an altitude of approximately $540 \mathrm{~m}$, inside polyethylene pots arranged in a growth chamber and regulated at $28^{\circ} \mathrm{C}$, with relative humidity of $80 \%$ and 14 hours of light.

\section{The weather}

The region climate is tropical humid type Cwa according to Köppen classification with dry and mild winter, mean annual temperature of $23.9^{\circ} \mathrm{C}-$ maximum of $30.3^{\circ} \mathrm{C}$ and minimum of $19.1^{\circ} \mathrm{C}$ - mean annual precipitation of $1,273.3 \mathrm{~mm}$, with July as the driest month and January as the rainiest (Inmet, 2017). Figures contain data collected at the meteorological station located close to the experimental area.

\section{Experimental design}

The experimental design was completely randomized in a factorial scheme $7 \times 5$ and assessed seven glyphosate doses: 0 (control), 720, 960; 1200, 1440, 1680, 1920 g.i.a. ha ${ }^{-1}$; applied in five invasive plants: 1 - Black picket (Bidens pilosa L.); 2 - Ragged (Commelina benghalensis L.); 3 - Bitter grass 
(Digitaria insularis L. (Fedde)); 4 - Viola string (Ipomoea grandiofolia L.), and 5 - Bull herb (Tridax procumbens L.) with five repetitions. The seeds of invasive plants were obtained from a company which produces seeds of weeds.

These weeds were initially sowed in a polyethylene box and upon presenting a definitive pair of leaves, transplanted to $9.5 \mathrm{~cm}$ diameter pots containing PlantaMax ${ }^{\circledR}$ substrate at a density of three plants per pot. Glyphosate applications commercial product Roundup Ready ${ }^{\circledR}$ by Monsanto do Brasil - at $480 \mathrm{~g} \mathrm{~L}^{-1}$ of i.a. were carried out 25 days after the emergence of invasive plants when presenting development stage of two to six perennial leaves. These applications were performed using a laboratory sprayer (spray chamber) at a pressure of $279.3 \mathrm{Kpa}$, with the tip 110.02 , which applies a volume of $300 \mathrm{~L} \mathrm{ha}^{-1}$ of the liquid at a temperature of $25^{\circ} \mathrm{C}$ and a relative humidity between 60 and $70 \%$.

\section{Assessments}

The assessment of control were conducted on days 7, 14, and 21 after treatment (DAA) with glyphosate application and attributed scores from 0 to $100 \%$ considering the following control classification: Excellent $=100$ to $91 \%$; Very good = 91 to $80 \%$; Good = 81 to $70 \%$; Sufficient $=71$ to $60 \%$; Regular $=60$ to $41 \%$; None or poor $=40$ to $0 \%$, according to the scale of the Latin American Weed Association (Alam, 1974).

The remaining weeds (live or dead) were cut close to the neck region with scissors on day 21 DAA, placed in paper bags identified for drying process through a forced-air circulation chamber at $65^{\circ} \mathrm{C}$ for 72 hours to determine the dry biomass of the species.

\section{Statistical analysis}

Data were subjected to an analysis of variance by using the statistical software SANEST. For the significant qualitative analysis (weed species) in the F Test, we compared the mean values through Tukey's test at a $5 \%$ limit. We performed the qualitative analysis of glyphosate doses with a regression by choosing the model which presented the highest significance on Sigmaplot Software version 2010.

\section{Conclusion}

Glyphosate controlled the species B. pilosa and D. insularis considering that $100 \%$ of them died 14 days after its application (DAA) at $720 \mathrm{~g} \mathrm{ha}^{-1}$ i.a. The glyphosate dose required to achieve control indices above $91 \%$ was $1680 \mathrm{~g}$ $\mathrm{ha}^{-1}$ i.a. for C. grandifolia, $960 \mathrm{~g} \mathrm{ha}^{-1}$ i.a. for T. procumbens, and $1440 \mathrm{~g} \mathrm{ha}^{-1}$ i.a. for I. grandifolia on day $21 \mathrm{DAA}$, therefore considered difficult to control. It is recommended to apply $1440 \mathrm{~g}$ ha-1 i.a. of glyphosate for effective control over $80 \%$ for all the invasive plants assessed on day 21 DAA.

\section{Acknowledgments}

The authors would like to thank the Postgraduate Course in Agronomy / Phytotechnics of the Luiz de Queiroz Higher School of Agriculture (ESALQ), the National Council for Scientific and Technological Development (CNPq) for granting the scholarship, and all those who directly or indirectly collaborated to the development of this research.

\section{References}

Association Latinoamericana de Malezas (ALAM) (1974) Recomendaciones sobre unificación de los sistemas de evaluación en ensayos de control de malezas. 1: 35-38.

Carvalho SJP, Dias ACR, Damin V, Nicolai M, Christoffoleti PJ (2008) Glyphosate aplicado com diferentes concentrações de uréia Ou sulfato de amônio para dessecação de plantas daninhas. P Agr Br. 43: 1501-08.

Christoffoleti PJ, López-Ovejero RF (2008) Resistência das plantas daninhas a herbicidas: definições, bases e situação no Brasil e no mundo. In: Christoffoleti PJ Aspectos de resistência de plantas daninhas a herbicidas. 3a.ed. Piracicaba: HRAC-BR, p. 3-30.

Christoffoleti PJ, Galli AJ, Carvalho SJ, Moreira MS, Nicolai M, Foloni LL, Martins BA, Ribeiro DN (2008) Glyphosate sustainability in South American cropping systems. Pest Man Sci. 64: 422-27.

Correia NB, Durigan JC, Leite GJ (2008) Seletividade da soja transgênica tolerante ao glyphosate e eficácia de controle de Commelina benghalensis com herbicidas aplicados isolados e em misturas. Br. 67: 663-71.

Dalazen G, Kruse ND, Machado SLO, Balbinot A (2015) Sinergismo na combinação de glyphosate e saflufenacil para o controle de buva. P Agr Trop. 45: 249-56.

Ferreira EA, Concenço G, Vargas L, Silva AA (2009) Manejo de plantas daninhas tolerantes ou resistentes ao glyphosate no Brasil. In: Velini ED, Meschede DK, Carbonari C.A., Trindade M.L.B. Glyphosate. Botucatu: FEPAF, c. 15, p. 357-400.

Foloni LL, Rodrigues D, Ferreira F, Miranda R, Ono EO (2005) Aplicação de glyphosate em pós-emergência, em soja transgênica cultivada no cerrado. R Br Herb. 4: 47-58.

Ikeda FS (2013) Resistência de plantas daninhas em soja resistente ao glyphosate. Inf Ag. 34: 1-8.

Instituto Nacional De Meteorologia (INMET). Boletim Climatológico do - São Paulo estado de São Paulo - SP, fevereiro/2017. Available from: http://www.inmet.gov.br/portal/index.php?r=home/page \&page=nota_tecnica-03/17. Access on: May 1st, 2018.

Kissmann KG (2013) Resistência de plantas daninhas a herbicidas. Paulínea: Associação Brasileira de Ação à Resistência de Plantas Daninhas aos Herbicidas-HRAC, 32p.

Koger CH, Reddy KN (2005) Role of absorption and translocation in the mechanism of glyphosate resistance in horseweed (Conyza canadensis). We Sci. 53: 84-9.

Marchi SR, Bogorni D, Biazzi L, Bellé, JR (2013) Associações entre glyphosate e herbicidas pós-emergentes para o controle de trapoeraba em soja $\mathrm{RR}^{\circledR}$. R Br Herb. 12: 23-30.

Monquero PA, Cury JC, Christoffoleti PJ (2005) Controle pelo glyphosate e caracterização geral da superfície foliar de Commelina benghalensis, Ipomoea hederifolia, Richardia brasiliensis e Galinsoga parviflora. PI Dan. 23: 123- 32.

Moreira MS, Nicolai MI, Carvalho SJPI, Christoffoleti PJ (2007) Resistência de Conyza canadensis e C. bonariensis ao herbicida glyphosate. PI Dan. 25: 157-64.

Procópio SO, Menezes CCE, Betta L, Betta, M (2007) Utilização de chlorimuron-ethyl e imazethapyr na cultura da soja Roundup Ready. PI Dan. 25: 365-73.

Ramires AC, Constantin J, Oliveira Junior RS, Guerra N, Alonso DG, Raimondi MA (2011) Glyphosate associado a outros herbicidas no controle de Commelina benghalensis e Spermacoce latifólia. Sem. 32: 883-96. 
Ramires AC (2011) Controle de Euphorbia heterophylla e Ipomoea grandifolia com a utilização de glyphosate isolado ou em associação com latifolicidas. PI Dan. 28: 62129.

Rodrigues BN, Almeida FS (2011) Guia de herbicidas. 6a.ed. Londrina: Ed. dos AAs, 697p.

Santos ICl, Silva AA, Ferreira FA, Miranda GV, Pinheiro RAN (2001) Eficiência de glyphosate no controle de Commelinea benghalensis e C. diffusa. PI Dan. 19: 135-41.

Takano HK (2013) Efeito da adição do 2,4-D ao glyphosate para o controle de espécies de plantas daninhas de difícil controle. R Br Herb. 12: 1-13.
Timossi PC, Durigan JC, Leite GJ (2006) Eficácia de glyphosate em plantas de cobertura. PI Dan. 24: 475-80.

Vidal RA (2014) Fatores ambientais que afetam a eficácia de glyphosate: síntese do conhecimento. Pesticidas: R. Ec M Amb. 24: 43-52.

Yamauti M, Barroso AAM, Souza MC (2010) Controle químico de biótipos de buva (Conyza canadensis e Conyza bonariensis) resistentes ao glyphosate. R Ci Agron. 41: 495-500. 